\title{
An Assessment of Nested PCR to Detect Phytoplasmas in Imported Dormant Buds and Internodal Tissues of Quarantined Tree Fruit Germ Plasm
}

\author{
H. E. Waterworth, plant pathologist, and Ray Mock, support scientist, USDA, ARS, Plant Quarantine Office, \\ Bldg. 580, Beltsville, MD 20705
}

\begin{abstract}
Waterworth, H. E., and Mock, R. 1999. An assessment of nested PCR to detect phytoplasmas in imported dormant buds and internodal tissues of quarantined fruit tree germ plasm. Plant Dis. 83:1047-1050.

Nested polymerase chain reaction (PCR) assays were evaluated for use on a routine basis in a quarantine program to detect phytoplasmas in dormant fruit tree scionwood collected during the winter season. Phytoplasmas associated with peach yellow leaf roll, Western X, apricot chlorotic leaf roll, plum leptonecrosis, and apple proliferation diseases were detected in all known infected sources. Phytoplasmas in Prunus spp. were readily detected in both dormant bud and internodal tissues. Use of nested PCR versus a single primer pair resulted in electrophoresed PCR products that were easier to interpret. The nested PCR procedure has replaced 3-year tests with grafts on sensitive indicators to detect this group of pathogens.
\end{abstract}

Additional keyword: Malus

Diseases of deciduous fruit crops associated with phytoplasmas have been reported worldwide $(23,25)$. Some, such as peach yellows and cherry Western $\mathrm{X}$ diseases, are well known for having caused considerable losses in past years $(12,27)$. Others, such as apple proliferation (14) and Moliere's cherry diseases, continue to cause major problems for fruit production in parts of Europe (1). Pathogens associated with Western X and peach yellows diseases are well established in the United States, but many others are not, including phytoplasmas associated with diseases known as apricot, plum, and peach chlorotic leaf roll $(15,16,23)$; plum leptonecrosis $(16,25)$ and chlorosis $(23)$; peach vein clearing (6); plum, peach, and apricot decline $(15,16,23)$; cherry lethal yellows (8); European stone fruit yellows (8); and proliferation of apple trees (14). Additional reports appear regularly that describe the association of phytoplasmas with various diseases $(3,6,20,26)$.

Many scientists have categorized major phytoplasmas into groups based on restriction fragment length polymorphism or phylogenetic analyses of $16 \mathrm{~S}$ rRNA gene se-

Corresponding author: H. Waterworth

E-mail:pgqohw@ars-grin.gov

Mention of a specific product is not intended to be an endorsement of that product to the exclusion of similar products that may be available.

Accepted for publication 13 August 1999.

Publication no. D-1999-0915-01R

This article is in the public domain and not copyrightable. It may be freely reprinted with customary crediting of the source. The American Phytopathological Society, 1999. quences of different phytoplasmas $(1,2,7$, $12,13,16,19,26)$. However, the relationship among many phytoplasmas that infect fruit and shade trees in different geographic regions has not been clarified. As a result, the distribution of related pathogens among countries also remains unknown. For this and other reasons, vegetative propagules of fruit crops are quarantined and tested for phytoplasmas upon arrival in the United States $(9,31)$.

A number of procedures have been described for detecting phytoplasmas in plant tissues, including Southern blot hybridization $(3,12)$, electron microscopy (29), a fluorescence technique with the DNA fluorochrome 4',6'-diamidino-2-phenylindole (DAPI) $(3,15,22)$, serological tests (7, $12,17)$, and grafting to sensitive woody indicator cultivars $(8,25,31)$. All of these procedures have various shortcomings in terms of sensitivity, reliability, and time of year during which testing can be conducted. Many researchers have commented on the problems associated with these methods $(3,4,11$, 13,29).

One of the newer procedures evaluated for detection of phytoplasmas in plants is polymerase chain reaction (PCR) on extracted nucleic acids combined with gel electrophoresis of the amplified product. PCR is rapid and more sensitive than other procedures in detecting phytoplasmas in fruit crops $(2,4,6,12,15,18,19,22,26)$, shade trees $(2,3,16,19,26)$, grasses $(20,24)$, and medicinal $(24,26)$, vegetable, and ornamental crops $(2,19,26)$. In most instances, tissues examined have been succulent structures, such as growing points, pedicles, petioles, and leaf midribs. Tree fruit crop germ plasm, however, is exchanged between countries in the form of woody dormant budwood, not only because the form remains true-to-type when propagated but because it also can be successfully established in the recipient country on domestic rootstocks. In the past, tests for phytoplasmas could not begin until certain herbaceous tissues were available from established trees, or, if tests were conducted by grafting to sensitive woody indicators, waiting for several years for symptoms to develop.

One objective of the U.S. Department of Agriculture's (USDA) plant quarantine program is to complete tests for pathogens as soon as possible consistent with minimizing risks of importing pathogens from other countries $(9,31)$. One purpose of our research project was to determine whether a PCR procedure could detect phytoplasma DNA extracted from dormant woody tissues upon arrival in the United States. There are reports of phytoplasmas detected using PCR in dormant woody tissues. Carraro et al. (5) and Green et al. (10) detected phytoplasmas from buds and bark shavings, respectively, of cherry and peach scionwood, as did Seemüller (30) from phloem preparations of various stone fruit species. Phytoplasmas also have been detected in dormant wood of pears (10). It is not clear in most instances whether bud or internodal dormant tissues were tested or whether phytoplasmas have been detected from dormant scionwood of apple, apricot, almond, and plum.

Our objective was to determine whether use of bud tissue is essential or internodal tissue will suffice and whether the procedures used can detect a phylogenetically broad range of phytoplasmas. Finally, we wanted to evaluate for the USDA quarantine program the virtues of the nested PCR procedure, as described $(11,18,20,29)$, compared with PCR amplification with a single primer pair.

\section{MATERIALS AND METHODS}

Dormant budwood of cherry and peach infected with Western $\mathrm{X}$ and yellow leaf roll diseases caused by phytoplasmas, respectively, were provided by B. Kirkpatrick and J. Uyemoto (Davis, CA). Additional phytoplasma-infected and healthy dormant Prunus spp. and apple budwoods, collected during the winter season, were provided by E. Seemüller (Dossenheim, Germany). Dormant apple budwood from healthy trees and trees with proliferation disease was available locally from S. Hurtt (Beltsville, MD). 
All tests were conducted on budwood from known phytoplasma-infected or -free trees. Nucleic acid extractions were conducted on a total of 66 samples of dormant budwood after 2 to 4 months at $4^{\circ} \mathrm{C}$ and on 16 scions taken from growing trees during late summer in a series of five experiments. Approximately 200 PCR and gel-electrophoresis tests were performed with the extractions in a series of experiments in which several variables were evaluated. In other cases, selected samples were compared in a given test, such as infected almond versus plum or buds versus internodal tissues.

Universal primer pairs $\mathrm{R} 16 \mathrm{mF} 2 / \mathrm{R} 16 \mathrm{mR} 1$ and R16F2n/R16R2 were designed previously by Gundersen and Lee (11) to amplify $16 \mathrm{~S}$ rDNA sequences among phytoplasma strains. In nested PCR, the former pair was used in the initial amplification, whereas the second primer pair, R16F2n/ R16R2, was used for the second (nested) amplification $(11,16)$. Primer pair R16F2/ R16R2 was used in a single amplification (Fig. 1A). For total nucleic acid extractions, samples $(0.15 \mathrm{~g})$ consisting of either scrapings of internodal inner bark or dormant bud tissues were excised and triturated for $10 \mathrm{~s}$ in $2.0 \mathrm{ml}$ of cold extraction buffer (21) with a homogenizer (Kleco, Kinetic Laboratory Equipment Co., Visalia, CA). The resultant homogeneous slurry was processed according to standard published procedures $(2,21)$.

To conduct PCR assays, nucleic acid extracts were analyzed with a spectrophotometer and diluted to $20 \mathrm{ng} / \mu \mathrm{l}$ in sterile deionized water. Reactions were performed in a total of $50 \mu \mathrm{l}$ of a mixture containing
$100 \mathrm{ng}$ of total nucleic acids, $5 \mu \mathrm{l}$ of 10XPCR Buffer II (Perkin-Elmer-Roche, Branchburg, $\mathrm{NJ}), 3 \mu \mathrm{l}$ of $25 \mathrm{mM} \mathrm{MgCl}{ }_{2}, 1 \mu \mathrm{l}$ of $10 \mathrm{mM}$ dNTPs, $1 \mu \mathrm{g}$ of each primer in the primer pair, $33.7 \mu \mathrm{l}$ of sterile nuclease-free water, and 1.5 units of AmpliTaq Gold (Perkin-Elmer, Foster City, CA). PCR assays were conducted in an automated thermocycler (Hybaid Instruments, Holbrook, NY), with the following parameters: 1 cycle of $10 \mathrm{~min}$ at $94^{\circ} \mathrm{C}$ for enzyme activation; 35 cycles of $1 \mathrm{~min}$ at $94^{\circ} \mathrm{C}$ for denaturation and $2 \mathrm{~min}$ at $50^{\circ} \mathrm{C}\left(60^{\circ} \mathrm{C}\right.$ for nested amplification with primer pair R16F2n/R16R2) for annealing; 1 cycle of $3 \mathrm{~min}$ at $72^{\circ} \mathrm{C}$ for extension; and 1 cycle of $10 \mathrm{~min}$ at $72^{\circ} \mathrm{C}$ for primer extension (19). Tubes devoid of added DNA template were included in each experiment as negative controls. Template from the initial amplification was diluted $1: 30$, and $5 \mu \mathrm{l}$ was subjected to the thermocycler conditions described above with primer pair $\mathrm{R} 16 \mathrm{~F} 2 \mathrm{n} / \mathrm{R} 16 \mathrm{R} 2$ for the nested amplification step.

Nested PCR products were subjected to electrophoresis in $5 \%$ polyacrylamide gels on a vertical slab gel apparatus. The second PCR product $(3 \mu \mathrm{l})$ mixed with $3 \mathrm{ml}$ of dye and $2 \mu$ of Tris-EDTA buffer was loaded on gels and electrophoresed (10). Bands were noted after staining with silver nitrate; gels were dried and photographed. Product sizes were determined with a $10-\mathrm{kb}$ molecular weight marker (BioMarker, BioVentures, Murfreesboro, TN).

\section{RESULTS AND DISCUSSION}

Phytoplasmas were detected in dormant buds from all trees known to be infected, including three or more trees each of apple, almond, apricot, cherry, peach, and plum. (Figs. 1 and 2). Phytoplasmas also were detected in internodal bark tissues of peach and cherry but not of apple. No phytoplasmaassociated band was observed for any fruit tree thought to be healthy. The universal primers used, described by Lee et al. (18, 19), detected phytoplasmas associated with cherry $\mathrm{X}$ and peach yellow leaf roll diseases from trees within the United States. These primers also repeatedly detected phytoplasmas from trees with apple proliferation disease and from infected peach, apricot, plum, and almond scionwood from Germany (labeled European stone fruit yellows). However, detection of phytoplasmas did not identify specific pathogens.

There are two reasons we did not attempt to identify specific mycoplasmas. The U.S. government's policy is to not allow any foreign germ plasm infected with phytoplasmas to enter the United States, therefore identification is not essential, and the etiology of diseases with phytoplasma-induced symptoms have not been well documented. Many researchers have addressed this issue, among them Schneider et al. (28) and Nakashima et al. (24) who found little correlation between identified diseases of various crops and the phytoplasmas detected in diseased plants. Lee et al. (16) found that two to four types of phytoplasmas are associated with each of the several identified diseases they studied and that a single plant can have multiple infections with different phytoplasmas. Conversely, other researchers were unable to detect any phytoplasmas in trees with typical disease symptoms (29). The phytoplasma found in stone fruit trees is a homogeneous organism that

A

B

$\begin{array}{lllllllllll}1 & 2 & 3 & 4 & 5 & 6 & 7 & 8 & 9 & 1011 & 12131415161718\end{array}$

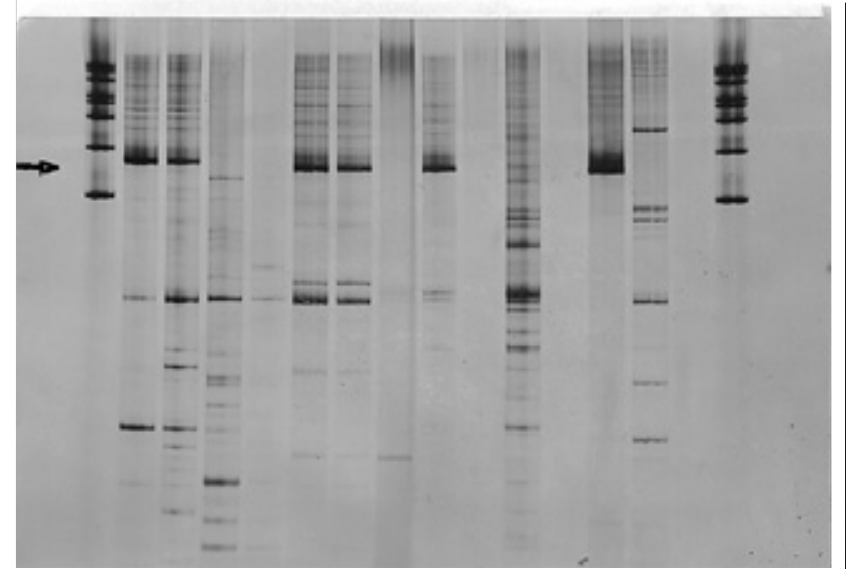

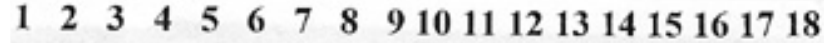

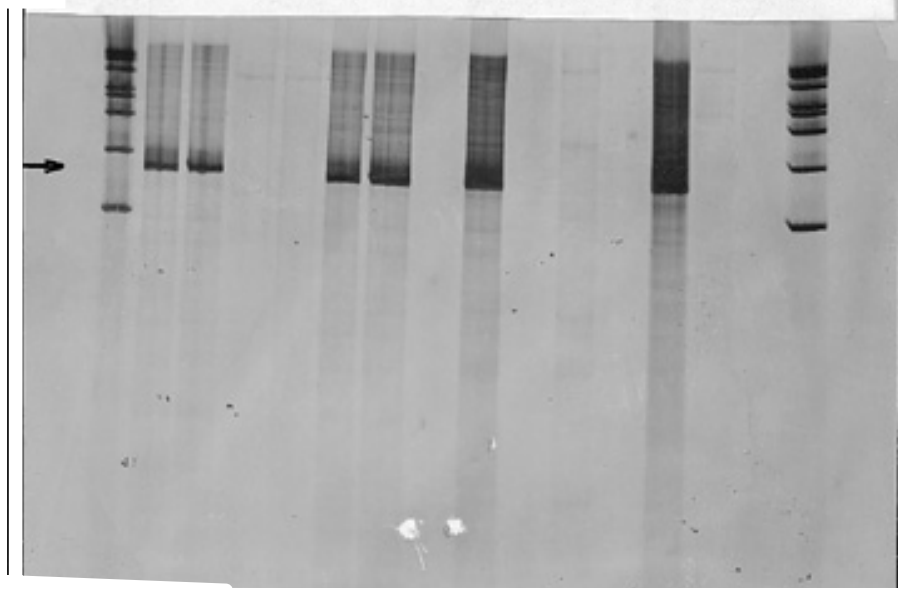

Fig. 1A-B. Single versus nested primers. Polyacrylamide gel electrophoretic patterns on nucleic acids (NA) extracted from phytoplasma-infected or healthy dormant woody apple, cherry, and peach tissues after polymerase chain reaction with (A) a single universal primer pair R16F2/R16R2 or (B) nested primer pair R16mF2/R16mR1 followed by R16F2n/R16R2. Sources of NA: lanes 3 and 4, cherry wood infected with Western X disease; lanes 7 and 8, peach infected with yellow leaf roll disease; lanes 10 and 11, apple with proliferation disease; lanes 3, 7, and 10, dormant buds; lanes 4, 8, and 11, internodal bark; lanes 5 and 6 , healthy cherry bud or bark tissue; lane 9, healthy peach bark or bud tissue; lanes 12 and 13 , health apple bud or bark tissue. Controls: lanes 14 and 15, aster yellows (AY1a)-infected and healthy periwinkle, respectively; lane 16, water blank; lanes 2 and 17, BioMarker 10-kb molecular weight markers; lanes 1 and 18, blanks. Several additional bands in the lower areas of the gels in A were eliminated by nested primers, as shown in B. Arrow indicates location of phytoplasma NA. 
is responsible for all known stone fruit phytoplasmoses in Europe, including apricot chlorotic leaf roll and plum leptonecrosis, as well as the pathogen associated with apple proliferation disease (2).

Although identification of the pathogens detected in our study was limited, it appears that they represent most of the major phylogenetic groups of phytoplasmas, as categorized by Lee et al. (16-19) and other researchers $(1,2,7,11,13,26,28)$.

PCR is considered the most sensitive method currently available for detection of plant-infecting phytoplasmas $(3,11,13,19)$. In comparative studies by other researchers, PCR provided more reliable results than other methods. For example, the sensitivity of PCR was reported as 1,000 times higher than dot hybridization of DNA extracts from infected periwinkle (2), and according to Schneider et al. (29), more samples were positive in PCR than in hybridization tests. PCR also was more sensitive than the DAPI test in detecting peach rosette (22), oak decline (3), and unspecified (2) phytoplasmas and more sensitive than serological or dot hybridization tests (11).

In our work, a single primer pair detected phytoplasmas in infected dormant budwood of all fruit types. However, electrophoresed gels of PCR products usually displayed several unidentified, probably host-nonspecific, DNA bands (Fig 1A), which is not uncommon. For example, Gundersen et al. (11) reported that sensitivity and specificity can be compromised, in that nonphytoplasma sequences can be coamplified making it difficult to unequivocally confirm the presence of phytoplasmas in electrophoresed gels. Furthermore, a single PCR amplification with one primer pair often fails to de- tect phytoplasma from infected woody hosts $(11,20)$.

An extra step involving use of a second universal primer pair provided an amplified product free of excess bands of low molecular weight materials (Fig. 1B). Other researchers have reported on the virtues of nested primers $(9,16,18,29)$. For example, the double set of universal primer pairs used in our study detected all 19 phytoplasmas examined by Gundersen et al. (11), which represented all known phytoplasma groups, with a sensitivity 100 -fold greater than a single primer pair. Schneider and Gibb (29) reported that nested primers detected phytoplasmas in more samples of pears with decline disease than did a single pair of universal primers.

There are many reports on the erratic distribution of phytoplasmas in plants, especially in trees $(3,17)$. Based on these reports, one might expect some budsticks from a given tree to test positive and others to test negative. Indeed, we did not detect phytoplasmas in some of the six budsticks from a large tree, while others from the same tree tested positive, making the need for thorough sampling, which was beyond the purpose of our experiments. In all cases, our samples were clearly positive or negative (Figs. 1 and 2).

It is widely believed that the titer of phytoplasmas in woody genera can be low or, when using non-PCR procedures, apparently absent during cold seasons (25). Foreign budwood examined in these studies was harvested during the winter season and was fully dormant, yet test results correlated well with the known health status of the source trees.

The ability to detect a broad spectrum of phytoplasmas associated with many widely recognized fruit tree diseases in dormant budwood could contribute considerably to reducing the spread of these pathogens among countries during exchange of plant germ plasm. When incorporated into a quarantine program, the nested primer PCR test could be conducted on germ plasm upon arrival in a country. The test is considered highly sensitive, which reduces the chance of importing foreign pathogens, and reduces the length of time imported fruit germ plasm spends in quarantine. Nested PCR has been accepted by U.S. regulatory officials as a suitable replacement for the former 3-year graft test on sensitive indicator cultivars.

\section{ACKNOWLEDGMENTS}

We thank B. Kirkpatrick, J. Uyemoto, R. Andersen, S. Hurtt, and E. Seemüller for providing the budwood for these studies; R. Davis for the aster yellows culture AY1a; and L. Levy, I. M. Lee, and L. Nemchinov for helpful guidance.

\section{LITERATURE CITED}

1. Ahrens, U., Lorenz, K.-H., and Seemüller, E. 1993. Genetic diversity among mycoplasmalike organisms associated with stone fruit diseases. Mol. Plant-Microbe Interact. 6:686-691.

2. Ahrens, U., and Seemüller, E. 1992. Detection of DNA of plant-pathogenic mycoplasmalike organisms by a polymerase chain reaction that amplifies a sequence of the $16 \mathrm{~S}$ rRNA gene. Phytopathology 82:828-832.

3. Ahrens, U., and Seemüller, E. 1994. Detection of mycoplasmalike organisms in declining oaks by polymerase chain reaction. Eur. J. For. Pathol. 24:55-63.

4. Avinent, L., and Llacer, G. 1995. Detection of phytoplasmas in fruit trees by polymerase chain reaction (PCR) in Spain. Acta Hortic. 386:480482.

5. Carraro, L., Nemchinov, L., and Hadidi, A. 1998. PCR detection of pome and stone fruit phytoplasmas from active or dormant tissue. Acta Hortic. 472:731-735.
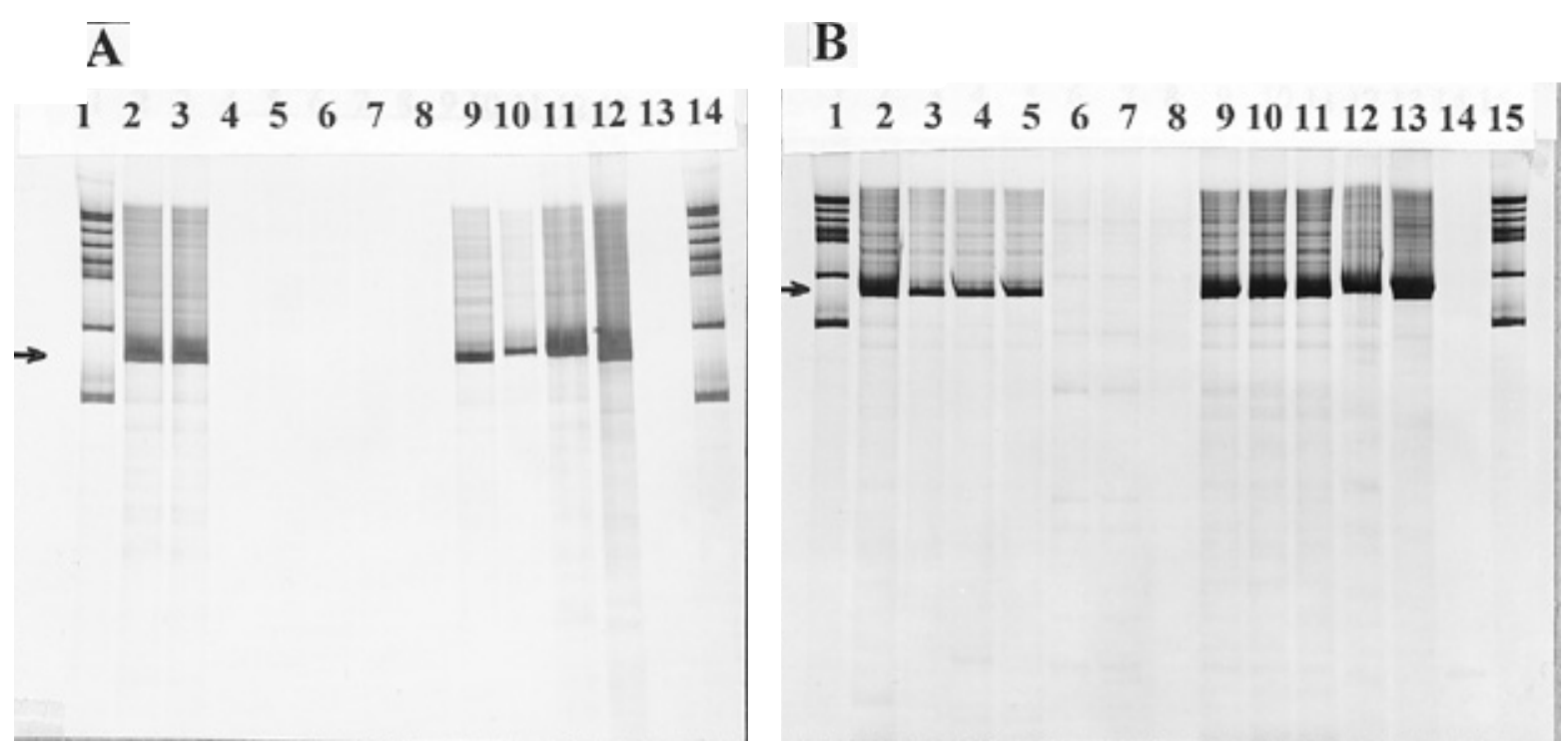

Fig. 2A-B. Polyacrylamide gel electrophoretic patterns on nucleic acids extracted from phytoplasma-infected and healthy dormant bud apple, cherry, peach, plum, and almond tissues after polymerase chain reaction assay with nested primer pair R16mF2/R16mR1 followed by R16F2n/R16R2 from apple with (A, lanes 2 and 3) and without (A, lanes 4 and 5) proliferation disease; peach with (B, lane 2) and without (A, lanes 6 through 8) peach yellow leaf roll disease; plum with (B, lanes 3 through 5, 9, and 11) and without (B, lanes 6 through 8) leptonecrosis disease; cherry with Western X disease (A, lanes 10 and 11; B, lane 12); almond with phytoplasma (A, lane 9). Controls: aster yellows from periwinkle (A, lane 12; B, lane 13); water blank (A, lane 13; B, lane 14); BioMarker 10-kb molecular weight markers in first and last lanes. Nonspecific bands were absent in lower areas of gels. Lanes with healthy and chlorotic leaf roll-infected apricot are not shown. 
6. Cornaggia, P., Gentit, P., Boye, R., and Desvignes, J. C. 1995. A new phytoplasma disease of apricot trees: The peach vein clearing. Acta Hortic. 386:448-453.

7. Davis, R. E., and Lee, I.-M. 1991. Mycoplasmalike organisms as plant disease agents-A review. Am. Type Cult. Collect. Q. Rev. 11:1-11.

8. Diekmann, M., and Putter, C. A. J. 1996. FAO/IPGRI technical guidelines for the safe movement of germplasm. No. 16: Stone Fruits. FAO of the United Nations, Rome/International Plant Genetic Resources Institute, Rome.

9. Foster, J. A. 1988. Regulatory actions to exclude pests during the international exchange of plant germplasm. HortScience 23:60-66.

10. Green, M. J., Thompson, D. A., and MacKenzie, D. J. 1999. Easy and efficient DNA extraction from woody plants for the detection of phytoplasmas by polymerase chain reaction. Plant Dis. 83:482-485.

11. Gundersen, D. E., and Lee, I.-M. 1996. Ultrasenstive detection of phytoplasmas by nestedPCR assays using two universal primer pairs. Phytopathol. Mediterr. 35:144-151.

12. Kirkpatrick, B. C., Gregory, A., Fisher, J. D., and Purcell, A. H. 1990. Epidemiological and phylogenetic studies on Western X-disease mycoplasma-like organisms. Zentralbl. Bakteriol. Suppl. 20:287-297.

13. Kirkpatrick, B. C., and Smart, C. D. 1995. Phytoplasmas: Can phylogeny provide the means to understand pathogenicity? Adv. Bot Res. 21:187-212.

14. Kunze, L. 1989. Apple proliferation. Pages 99-113 in: Virus and Virus-like Diseases of Pome Fruits and Simulating Noninfectious Disorders. P. R. Fridlund, ed. Wash State University Press, Pullman.

15. Lansac, M., Jarausch, W., and Dosba, F. 1995.
In vitro behaviour of different hosts infected with different fruit tree mycoplasma-like organisms. Acta Hortic. 386:454-463.

16. Lee, I.-M., Bertaccini, A., Vibio, M., and Gundersen, D. E. 1995. Detection of multiple phytoplasmas in perennial fruit trees with decline symptoms in Italy. Phytopathology 85:728-735.

17. Lee, I.-M., and Davis, R. E. 1988. Detection and investigation of genetic relatedness among aster yellows and other mycoplasmalike organisms by using cloned DNA and RNA probes. Mol. Plant-Microbe Interact. 1:303-310.

18. Lee, I. -M., Gundersen, D. E., Hammond, R. W., and Davis, R. E. 1994. Use of mycoplasmalike organism (MLO) group-specific oligonucleotide primers for nested-PCR assays to detect mixed-MLO infections in a single host plant. Phytopathology 84:559-566.

19. Lee, I.-M., Hammond, R. W., Davis, R. E., and Gundersen, D. E. 1993. Universal amplification and analysis of pathogen 16s rDNA for classification and identification of mycoplasmalike organisms. Phytopathology 83:834842.

20. Lee, I.-M., Pastore, M., Vibio, M., Danielli, A., Attathom, S., Davis, R. E., and Bertaccini, A. 1996. Detection and characterization of a phytoplasma associated with annual blue grass (Poa annua) a white leaf disease in Southern Italy. Eur. J. Plant Pathol. 103:251-254.

21. Malisano, G., Firrao, G., and Locci, R. 1996. 16S rDNA-derived oligonucleotide probes for the differential diagnosis of plum leptonecrosis and apple proliferation phytoplasmas. EPPO Bull. 26:421-428.

22. Marcone, C., Di Serio, F., and Ragozzino, A. 1995. Peach rosette: A disease associated with mycoplasma-like organisms. Acta Hortic. 386: $471-479$
23. McCoy, R. E. 1989. Plant diseases associated with mycloplasma-like organisms. Pages 545 623 in: The Mycoplasmas, vol. 5. R. F. Whitcomb and J. G. Tully, ed. Academic Press, New York.

24. Nakashima, K., Hayashi, T., Chaleeprom, W., Wongkaew, P., and Sirithorn, P. 1996. Complex phytoplasma flora in Northeast Thailand as revealed by 16 s rDNA analysis. Ann. Phytopathol. Soc. Jpn. 62:57-60.

25. Nemeth, M. 1986. Virus, mycoplasma and rickettsia diseases of fruit trees. Martinus-Nijhoff Publishing, Boston

26. Okuda, S., Prince, J. P., Davis, R. E., Dally, E. L. and Lee, I.-M. 1997. Two groups of phytoplasmas from Japan distinguished on the basis of amplification and restriction analysis of $16 \mathrm{~s}$ rDNA. Plant Dis. 81:301-305.

27. Pine, T. S., and Gilmer, R. M. 1976. Peach yellows. Pages 91-95 in: Virus diseases and noninfectious disorders of stone fruits in North America. U.S. Dep. Agric, ARS Handb. 437.

28. Schneider, B., Ahrens, U., Kirkpatrick, B. C. and Seemüller, E. 1995. Classification of plant-pathogenic mycoplasma-like organisms using restriction-site analysis of Per-amplified 13 16s rDNA. J. Gen. Microbiol. 139:519 527.

29. Schneider, B., and Gibb, K. S. 1997. Detection of phytoplasmas in declining pears in Southern Australia. Plant Dis. 81:254-258.

30. Seemüller, E., Stotlz, H., and Kisona, H. 1998 Persistence of the European stone fruit yellows phytoplasma in aerial parts of Prunus taxa during the dormant season. J. Phytopathol. 146: 407-410.

31. Waterworth, H. E. 1993. Processing foreign plant germ plasm at the national plant germplasm quarantine center. Plant Dis. 77:854-860. 